OPEN ACCESS

Edited by:

Xavier Pochon,

The University of Auckland,

New Zealand

Reviewed by:

Athanasios Mogias,

Democritus University of Thrace,

Greece

James Nikitine

Blue Cradle Foundation, New Zealand

*Correspondence:

Diana Boaventura

d.boaventura@netcabo.pt

Specialty section:

This article was submitted to

Marine Ecosystem Ecology,

a section of the journal

Frontiers in Marine Science

Received: 02 March 2021 Accepted: 07 September 2021

Published: 28 September 2021

Citation:

Boaventura D, Neves AT, Santos J, Pereira PC, Luís $C$,

Monteiro A, Cartaxana A, Hawkins SJ, Caldeira MF and Ponces de Carvalho A (2021)

Promoting Ocean Literacy in Elementary School Students Through Investigation Activities

and Citizen Science.

Front. Mar. Sci. 8:675278. doi: 10.3389/fmars.2021.675278

\section{Promoting Ocean Literacy in Elementary School Students Through Investigation Activities and Citizen Science}

\author{
Diana Boaventura ${ }^{1,2 *}$, Ana Teresa Neves ${ }^{1,3}$, Jaime Santos ${ }^{1}$, Paula Colares Pereira ${ }^{1}$, \\ Cristina Luís ${ }^{4,5}$, António Monteiro ${ }^{4}$, Alexandra Cartaxana ${ }^{4,6}$, Stephen John Hawkins, ${ }^{7,8,9}$, \\ Maria Filomena Caldeira ${ }^{1}$ and António Ponces de Carvalho'
}

'Escola Superior de Educação João de Deus, Centro de Investigação e Estudos João de Deus, Lisbon, Portugal, ${ }^{2}$ MARE Marine and Environmental Sciences Centre, Laboratório Marítimo da Guia, Faculdade de Ciências da Universidade de Lisboa, Cascais, Portugal, ${ }^{3}$ Instituto de Educação, Universidade de Lisboa, Lisbon, Portugal, ${ }^{4}$ MUHNAC - Museu Nacional de História Natural e da Ciência, Universidade de Lisboa, Lisbon, Portugal, ${ }^{5}$ CIUHCT - Centro Interuniversitário de História das Ciências e da Tecnologia, Faculdade de Ciências da Universidade de Lisboa, Lisbon, Portugal, ${ }^{6}$ MARE Marine and Environmental Sciences Centre, Universidade de Lisboa, Lisbon, Portugal, ${ }^{7}$ School of Ocean and Earth Science, National Oceanography Centre Southampton, Waterside Campus, University of Southampton, Southampton, United Kingdom, ${ }^{8}$ Marine Biological Association of the United Kingdom, Plymouth, United Kingdom, ${ }^{9}$ School of Biological and Marine Sciences, University of Plymouth, Plymouth, United Kingdom

To enable the process of energy transition towards carbon neutrality, it is important to educate the community on the need for social, economic, environmental and institutional transformation, and to educate and inform citizens to participate proactively in this change. This study evaluated the effectiveness of participation by elementary school students in educational activities and citizen science actions in enhancing their scientific knowledge and skills related to Ocean Literacy in the context of climate change. The activities were directed to children (aged 9-11) and involved pre-service teachers, inservice teachers and researchers, in formal and non-formal contexts. A total of 329 elementary school students participated in interdisciplinary science activities, focusing on the cause \& effect of climate change in the ocean. They learned to identify rocky shore marine species used to monitor climate change and acquired ICT skills by inserting species observations in a biodiversity mapping platform. Finally, students worked collaboratively to communicate to the community what they have learned through an exhibition at the Museum João de Deus. To assess the impact of the activities on acquisition of scientific knowledge and skills by the students, a mixed methodology was applied using pre and post-tests, analysis of the data inserted by students in the platform, and content analysis of the students' work for the museum exhibition. The results of pre and post-tests revealed a significant increase in knowledge of the effects of climate change on the rocky shore species distribution, as well as of the importance of monitoring these species distribution. The data from the online biodiversity platform showed that $42 \%$ of the species identifications made by the students were correct. 
The ability of the students to communicate their learning to the wider community was evaluated by the scientific content, structure, presentation and creativity and of posters, models, videos and games produced. Most of students focused their communications and creations on the greenhouse effect, cause \& effect of climate change in the ocean and biodiversity. This study reinforces the importance of addressing Ocean Literacy and climate change through formal and non-formal educational activities with an investigative nature.

Keywords: Ocean Literacy, climate change, education, citizen science, elementary students, rocky shores

\section{INTRODUCTION}

Ocean Literacy can be defined as an "understanding of the ocean's influence on you - and your influence on the ocean" (National Oceanic and Atmospheric Administration, 2013). It constitutes a challenge for all society members: the general public especially in their role as consumers and their influence on policy and decision makers (Uyarra and Borja, 2016; Borja et al., 2020). To do this, there is a particular responsibility for scientists working with other professionals, especially educators working in partnership with children to develop greater Ocean Literacy across all society. Children better able to understand the importance of the ocean to humankind and communicate about the ocean in a meaningful way will influence their peers and families; moreover, when adults they will make informed and responsible decisions regarding the ocean, its role in regulating the planet's climate and sustainable use of its resources (Cava et al., 2005). This is aligned with the UN 2030 Agenda for Sustainable Development (UNESCO, 2017), which among other sustainable development goals (SDG) states: that it is crucial to "ensure inclusive and equitable quality education" (SDG 4), providing students with the knowledge and skills necessary to promote a more sustainable society; "take urgent action to combat climate change and its impact" (SDG 13); plus "conserve and sustainably use the oceans, seas and marine resources for sustainable development" (SDG14).

Educationalists must also react to this compelling need by defining relevant learning objectives and content and by introducing pedagogies on the ocean that empower learners (Santoro et al., 2017). Fauville et al. (2018) state that Ocean Literacy includes three dimensions: knowledge, communication, and decision-making. All of which are supported by the objectives of environmental education defined by UNESCO (1975), namely, awareness, attitude, skills and participation. Thus, it is essential to promote Ocean Literacy at early ages, starting right from the first years of schooling, by adding topics developing Ocean Literacy into curricula (Mogias et al., 2019; Stefanelli-Silva et al., 2019; ALLEA, 2020), such as, the effects of climate change on oceans.

Educational interventions are most successful when they focus on local, tangible, and actionable aspects of sustainable development, climate change and environmental education, especially those that can be addressed by individual behavior (Anderson, 2012). Engagement with climate change is of growing importance to young people, since they will be confronted with its effects throughout their entire lives and, as future decisionmakers, they will critically influence societal developments. Thus, education will play a central role in the transformation to a sustainable society (Körfgen et al., 2017).

Our study focused on promoting Ocean Literacy related to climate change cause \& effect on marine coastal ecosystems, involving elementary students in inquiry-science activities and a citizen science action. The seven essential principles identified as needed to support the definition of Ocean Literacy relate to the content knowledge that an ocean-literate person should understand by the end of secondary school and result of a comprehensive framework to encourage the inclusion of ocean sciences into curricula, based on the recognition of the lack of ocean-related subjects in formal education (Santoro et al., 2017). Our research investigated learning in elementary school children and tackled principles 5 and 6 and some of the fundamentals concepts listed in Cava et al. (2005) report, namely, (1) principle 5 "The ocean supports a great diversity of life and ecosystems" - major groups of organisms have many representatives living in the ocean; ocean habitats are defined by environmental factors, due to interactions of abiotic factors, ocean life is not evenly distributed temporally or spatially, i.e., it is "patchy"; zonation patterns of organisms along the shore are influenced by tidal ranges and waves; most of the world's population lives in coastal areas; and (2) principle 6 "The ocean and humans are inextricably interconnected" - humans affect the ocean in a variety of ways, the pollution leads to habitat degradation, as well as the endangerment, depletion, and extinction of ocean species; everyone is responsible for caring for the ocean, the ocean sustains life on Earth and humans must live in ways that sustain the ocean, individual and collective actions are needed to effectively manage ocean resources for all.

Many studies have contributed to the development of climate change education including the contribution of teachers to learning (Ratinen et al., 2013; Oversby, 2015) and the importance of the ideas, questions, science engagement and learning of the students themselves (McCright et al., 2013; Körfgen et al., 2017; Tolppanen and Aksela, 2018; Trott and Weinberg, 2020). Reviews have identified effective strategies for climate change education (Monroe et al., 2019), and on international perspectives regarding climate change pedagogy (Perkins et al., 2018). Approaching climate change education 
through rocky shore ecosystems with young children is not so common, although there have been some studies on marine and coastal environmental education in the context of global climate change (Berchez et al., 2016), or that analyzed the effect of instruction on children's knowledge of marine ecology, attitudes toward the ocean, and stances toward marine resource issues and hence Ocean Literacy (Cummins and Snively, 2000).

Citizen science refers to the engagement of non-professionals in scientific investigations by asking questions, collecting data, or interpreting results (Miller-Rushing et al., 2012). Due to advantages such as the amount of data that can be gathered over larger spatial and temporal scales, or the increased scientific literacy and awareness gained by the participants, the diversity and number of citizen science projects is rapidly growing (Bates et al., 2015). According to the level of participation in scientific research, citizen science projects can be categorized as: (1) Contributory, where the data are collected by citizens but the research is designed by professional scientists; (2) Collaborative, generally designed by scientists but where citizens also contribute to the design, analysis, or dissemination elements of the project; (3) Co-created, where citizens are actively involved in helping professional scientists through all stages of the project (Bonney et al., 2009; Miller-Rushing et al., 2012). Rocky shores have been the focus of citizen science aimed at adults, especially in the United Kingdom in recent years, such as, Capturing Our Coast project, which has led to some important papers on climate change responses and distribution of shore biota (Vye et al., 2020).

Citizen science programs are often seen as useful for developing, scientific knowledge, and increasing scientificreasoning skills among those who participate (Jordan et al., 2011). In the education field, Saunders et al. (2018) emphasize the important role that citizen science can play in school science education. They considered it particularly relevant to address current societal environmental sustainability challenges, since it engages the students directly with environmental science giving them an understanding of the scientific process and the skills to observe local manifestations of global challenges.

There is now widely accepted scientific evidence that the climate is rapidly changing as a result of anthropogenic greenhouse gas emissions), leading in the oceans to increasing temperatures, rising and stormier seas and reducing $\mathrm{pH}$ due to absorption of $\mathrm{CO}_{2}$ (IPCC, 2017). In marine ecosystems, rising atmospheric $\mathrm{CO}_{2}$ and climate change are associated with concomitant alterations in temperature, circulation, stratification, nutrient input, oxygen content, and ocean acidification, with potentially wide ranging biological effects (Doney et al., 2011). At the population level, responses to climate change will include changes in abundance, and shifts in spatial distribution of organisms, especially on geographic scales. Intertidal rocky habitats are at the margins of the terrestrial and marine realms; thus, species are subject to environmental challenges of aquatic and aerial climatic regimes (Helmuth et al., 2006). They have long-been used to measure responses to climate fluctuations (Southward, 1980) and more recent rapid climate change (Hawkins et al., 2009; Firth and Hawkins, 2011), especially in the North-east Atlantic (reviewed in Hawkins et al., 2019). In a global warming scenario, interactions such as competition, predation, and mutualism are changing due to shifts in individual interaction strength and the relative abundance of interacting species. Consequently, these changes can drive important local-scale changes in community dynamics, biodiversity, and ecosystem functioning, and can potentially alter large-scale patterns of distribution and abundance (Kordas et al., 2011).

Ocean time-series and spatial surveys can be used to elucidate temporal trends and empirical relationships between biological variables and environmental forcing. Therefore, the record and analyses of long-term data sets are essential for understanding climate change impacts on marine ecosystems (Doney et al., 2011). In the our study, it was not possible to obtain a longterm data of species distribution, but the overall aim was that children would understand the importance of monitoring distribution of species on rocky shores in an area, Portugal, where responses to climate change have been observed (e.g., Lima et al., 2007).

Our investigation was part of a research project "EDUMAR Educating for the Sea," which aimed to educate for the preservation and sustainability of the sea and its resources. The target of the project was to create, implement and evaluate educational inquiry science activities and school-aged children participation in citizen science action, focusing on the cause \& effect of climate change on rocky shore ecosystems. These educational inquiry activities assumed diverse formats, designed to be implemented in the classroom and out of school contexts, such as, science museums, field work and visits to research laboratories, and were directed to children (4th and 5 th grade) with the participation of pre-service teachers, inservice teachers, and researchers. The activities were related to the main theme of the project, with particular emphasis on the awareness of students regarding the importance of monitoring both physicochemical parameters of seawater and species distribution, involving citizen science through the insertion of data on species distribution in an online platform. The school community was also involved in citizen science activities, so that students recognized the importance of their participation, as citizens, in science production and in monitoring the effects of climate change.

We evaluated the efficacy of the participation in inquiry-based educational activities and citizen science action on the students' Ocean Literacy, particularly in: (1) their knowledge on the cause $\&$ effect of climate change and the importance of monitoring marine species distribution, (2) their development of skills, and (3) their integration of knowledge, skills and decision making in collaborative work to communicate results to the community.

\section{MATERIALS AND METHODS}

\section{Participants}

A total of 329 students of the 4th and 5th grades (aged 9-11 in the 4 th to 5 th years of formal education at school in Portugal) 
belonging to 14 classes within 8 elementary schools ( 4 public schools and 4 private schools of the Association of Jardins-Escolas João de Deus) from the Lisbon region (Portugal) participated in this study. The activities involved pre-service teachers, in-service teachers and researchers.

\section{Procedure}

As a part of the project students performed a set of activities related to the cause \& effect of climate change in intertidal rocky shores ecosystems, in a formal and nonformal context. Two particular aspects related to the effects of climate change in the ocean were addressed: (i) the importance of monitoring physical and chemical parameters of water and, (ii) the importance of monitoring rocky shore species distribution through citizen science, by inserting data in an online biodiversity platform.

Three educational activities related to cause \& effect of climate change on rocky shores and marine species distribution were analyzed.

\section{Museum Activities}

The students went to the National Museum of Natural History and Science (University of Lisbon) where they learned, with a team of researchers, issues related to climate change and its impact on marine biodiversity and also how they could identify rocky shore species and register them in the Biodiversity4All/iNaturalist app. This activity was divided in two parts. The first part was mostly theoretical fostering discussion about climate change with the help of infographics, photographs and a booklet provided to each student. Then, the researchers explained the field trip that the students would do afterwards. The rocky shore species that were selected for monitoring were also introduced. These included fourteen common intertidal species plus six species whose distribution has been affected by climate change (three species with observed increased distribution and three species with observed decrease distribution on their geographical limits along the Portuguese coast). The second part was mostly practical and students learned how to identify the selected intertidal species with the help of museum specimens collections and pictures. Students photographed the specimens and inserted the images on the Biodiversity4All platform, using an application on the tablet (iNaturalist). Pre- and inservice teachers supervised and helped students in these 3h sessions.

\section{Field Trip Activity}

All the students went for a field trip to the intertidal zone at Avencas beach, Portugal. Supervised by an adult (preservice teachers, in-service teachers and researchers), each group (5-6 students) explored the rocky platform during low tide, looking for a particular set of four species to find and register in iNaturalist app. The set of species that each group looked for included common species, and species with increased and decreased distribution limits due to climate change. During approximately $3 \mathrm{~h}$, students used tablets, took photos of the previously selected marine species, inserted the images and registered the specimens in the app.
Once they completed this task, they also inserted images of other taxa. The data collection was made by sampling over seven different dates between March and May (two classes per date).

\section{Exhibition}

Back in their school classrooms, students prepared, over a month, the collaborative work for an exhibition at the Museum João de Deus, in order to communicate their learnings to the community (general public).

Students worked cooperatively in all activities. In the museum and beach activities, the teachers organized working groups of approximately five students. For the work produced for the exhibition students were organized in small groups or as a class group, according to each in-service teacher and students' preference (Figure 1).

\section{Data Collection}

Data were collected through pre- and post-tests to students $(n=292)$, records of the image observations inserted in the Biodiversity4All platform by the students $(n=407)$, and the materials produced collaboratively by the students for the exhibition $(n=36)$.

In order to assess the students' previous knowledge, a pretest was applied to students before the beginning of National Museum of Natural History and Science activity. The same test was applied after the activity (post-test). These tests included four questions to assess the students learning on the cause $\&$ effect of climate change and the importance of monitoring species distribution: (1) What is climate change?; (2) Choose the correct options to complete the following image (greenhouse effect scheme); (3) What can happen to the species distribution with the increase of water temperature?; (4) How can we help the scientists studying the impact of climate change on species distribution?

To evaluate learning of the identification of coastal marine species, the observational data students inserted in the platform were analyzed. Each observation included a photograph and basic information such as species name, date and location. After each field trip, the data inserted on the Biodiversity4All platform by students was reviewed by the project team for validation and to evaluate performance by the students.

Finally, to assess the impact of the educational activities on the general scientific knowledge and skills development of the students, the materials they produced for the final exhibition were assessed. These three instruments allowed a methodological triangulation approach.

\section{Data Analysis \\ Pre- and Post-test}

The pre and post-tests were analyzed according to a percentagemarking scheme. Each correct answer received twenty-five points; each incomplete answer was scored as twelve and one half points; on multiple-choice questions the score value was divided by the number of correct options; each incorrect answer was scored as zero (0). Only the cases with both pre- 

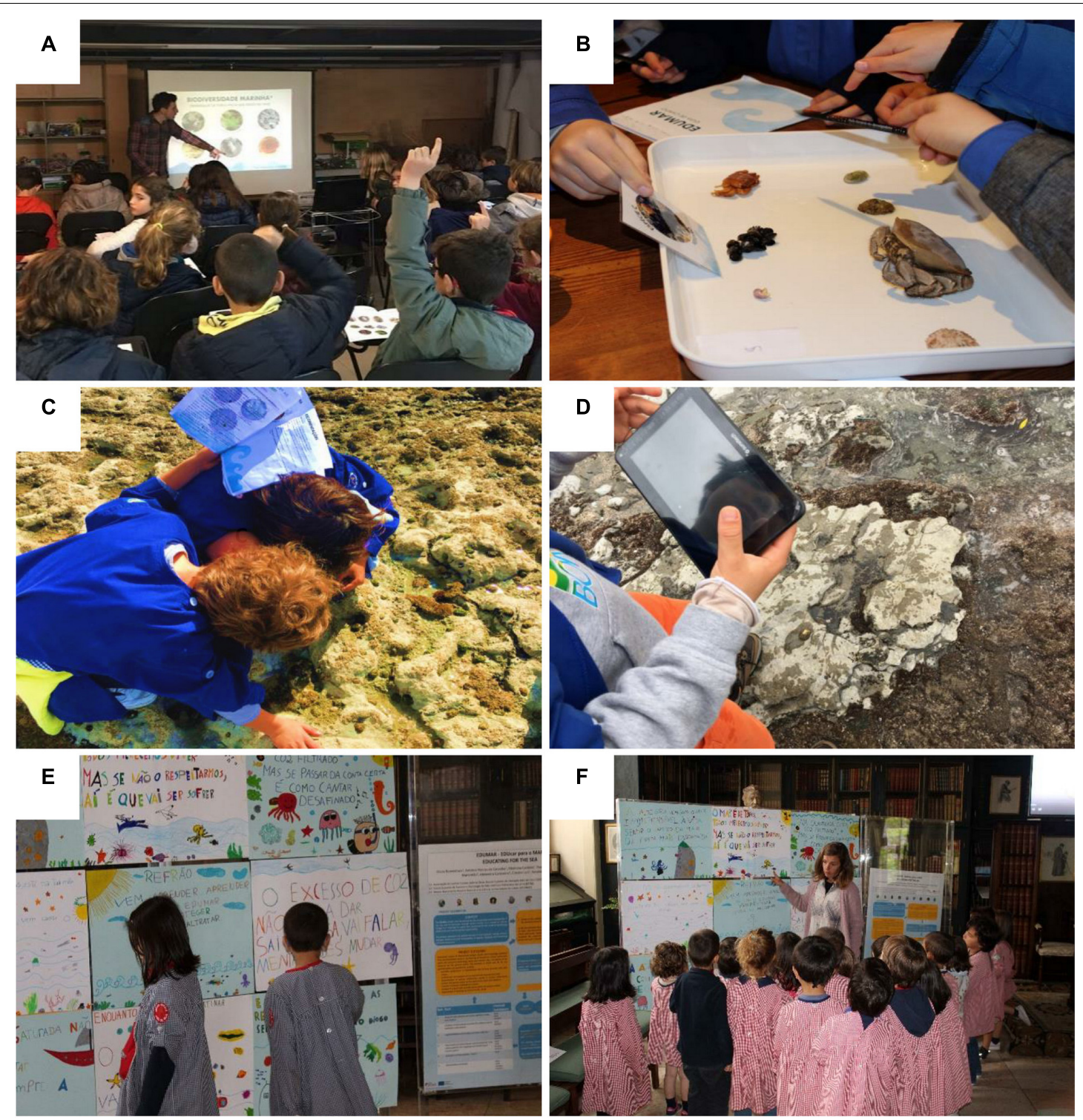

FIGURE 1 | The activities include (A) Part I, theoretical session at the National Museum of Natural History and Science (University of Lisbon). (B) Part II, practical session at the National Museum of Natural History and Science (University of Lisbon). (C,D) Field trip to Avencas Beach. (E,F) Final works exhibition at João de Deus Museum. All identifiable individuals have delivered a written consent for the publication of the images.

and post-tests for an individual student were considered for the analyses.

In order to assess students learning on cause \& effect of climate change and the importance of species distribution monitoring, the data analyses involved two steps. First, descriptive statistic was applied to portray relative frequencies of each question at pre- and post-test. Second, a non-parametric Wilcoxon (W) matched pair test for each student was used to look for significant differences in the score from the pre- and post-test. Statistical analyses were performed with the use of the Statistical Package for Social Sciences (SPSS v. 26). For all statistical tests, the significance level was predetermined at a probability value of 0.05 or less.

\section{Platform Data Analysis}

Data gathered via the Biodiversity4All portal was analyzed according to the percentage of correct species identification and number of taxa observed.

\section{Students' Work Content Analysis}

Students' collaborative work, made for the final exhibition, were analyzed through content analysis based on the following categories: content (objectives, scientific contents, ideas and development), structure and presentation (general organization, vocabulary and scientific style), and creativity (originality and used resources) (Table 1). 
TABLE 1 | Rubric for content analysis of the final works produced by the students.

\begin{tabular}{|c|c|c|c|c|c|}
\hline Section & Level items & 1 & 2 & 3 & 4 \\
\hline \multirow[t]{3}{*}{ Content } & Objectives & $\begin{array}{l}\text { The work was not } \\
\text { framed, not } \\
\text { objective and/or } \\
\text { other themes were } \\
\text { included }\end{array}$ & $\begin{array}{l}\text { The work includes } \\
\text { some information } \\
\text { on the topic but in } \\
\text { an unclear and } \\
\text { unobjective way }\end{array}$ & $\begin{array}{l}\text { The work has information } \\
\text { on the topic, in a clear and } \\
\text { objective way, but } \\
\text { containing some } \\
\text { superfluous information }\end{array}$ & $\begin{array}{l}\text { The work is framed, } \\
\text { clear and objective, } \\
\text { highlighting } \\
\text { fundamental } \\
\text { aspects }\end{array}$ \\
\hline & Scientific concepts & $\begin{array}{l}\text { The work presents } \\
\text { many inaccuracies } \\
\text { in scientific } \\
\text { concepts and } \\
\text { collected } \\
\text { information }\end{array}$ & $\begin{array}{l}\text { The work presents } \\
\text { some inaccuracies } \\
\text { in scientific } \\
\text { concepts and } \\
\text { collected } \\
\text { information }\end{array}$ & $\begin{array}{l}\text { The work presents few } \\
\text { inaccuracies in scientific } \\
\text { concepts and collected } \\
\text { information, but there is no } \\
\text { interconnection of concepts }\end{array}$ & $\begin{array}{l}\text { The work correctly } \\
\text { explains and } \\
\text { interconnects the } \\
\text { concepts and } \\
\text { information }\end{array}$ \\
\hline & $\begin{array}{l}\text { Ideas and } \\
\text { development }\end{array}$ & $\begin{array}{l}\text { The work presents } \\
\text { an insufficient } \\
\text { development of the } \\
\text { theme with few or } \\
\text { no details }\end{array}$ & $\begin{array}{l}\text { The work presents } \\
\text { an adequate } \\
\text { development of the } \\
\text { theme with some } \\
\text { details }\end{array}$ & $\begin{array}{l}\text { The work presents a good } \\
\text { development of the theme } \\
\text { with many support details }\end{array}$ & $\begin{array}{l}\text { The work presents } \\
\text { an extensive } \\
\text { development of the } \\
\text { theme with the } \\
\text { main idea } \\
\text { supported in detail }\end{array}$ \\
\hline \multirow[t]{2}{*}{ Structure and presentation } & $\begin{array}{l}\text { General } \\
\text { organization }\end{array}$ & $\begin{array}{l}\text { The work is not } \\
\text { organized }\end{array}$ & $\begin{array}{l}\text { The work has some } \\
\text { organization but } \\
\text { lacks of sequence }\end{array}$ & $\begin{array}{l}\text { The work is well organized } \\
\text { and with an evident } \\
\text { sequence }\end{array}$ & $\begin{array}{l}\text { The work is very } \\
\text { well organized, with } \\
\text { a good sequence } \\
\text { and subdivided into } \\
\text { subjects }\end{array}$ \\
\hline & $\begin{array}{l}\text { Vocabulary and } \\
\text { scientific style }\end{array}$ & $\begin{array}{l}\text { The work uses poor } \\
\text { and inadequate } \\
\text { vocabulary }\end{array}$ & $\begin{array}{l}\text { The work uses } \\
\text { sufficient but simple } \\
\text { vocabulary }\end{array}$ & $\begin{array}{l}\text { The work uses a good and } \\
\text { clear vocabulary }\end{array}$ & $\begin{array}{l}\text { The work uses an } \\
\text { excellent } \\
\text { vocabulary and } \\
\text { includes complex } \\
\text { and meaningful } \\
\text { words }\end{array}$ \\
\hline Creativity & $\begin{array}{l}\text { Originality and used } \\
\text { resources }\end{array}$ & $\begin{array}{l}\text { Presentation of the } \\
\text { work is not creative } \\
\text { at all in both } \\
\text { content and } \\
\text { materials used }\end{array}$ & $\begin{array}{l}\text { Presentation of the } \\
\text { work is not very } \\
\text { creative in content } \\
\text { and materials used }\end{array}$ & $\begin{array}{l}\text { Presentation of the work } \\
\text { has several creative } \\
\text { aspects in content and } \\
\text { materials used }\end{array}$ & $\begin{array}{l}\text { Presentation of the } \\
\text { work is extremely } \\
\text { creative in content } \\
\text { and materials used }\end{array}$ \\
\hline
\end{tabular}
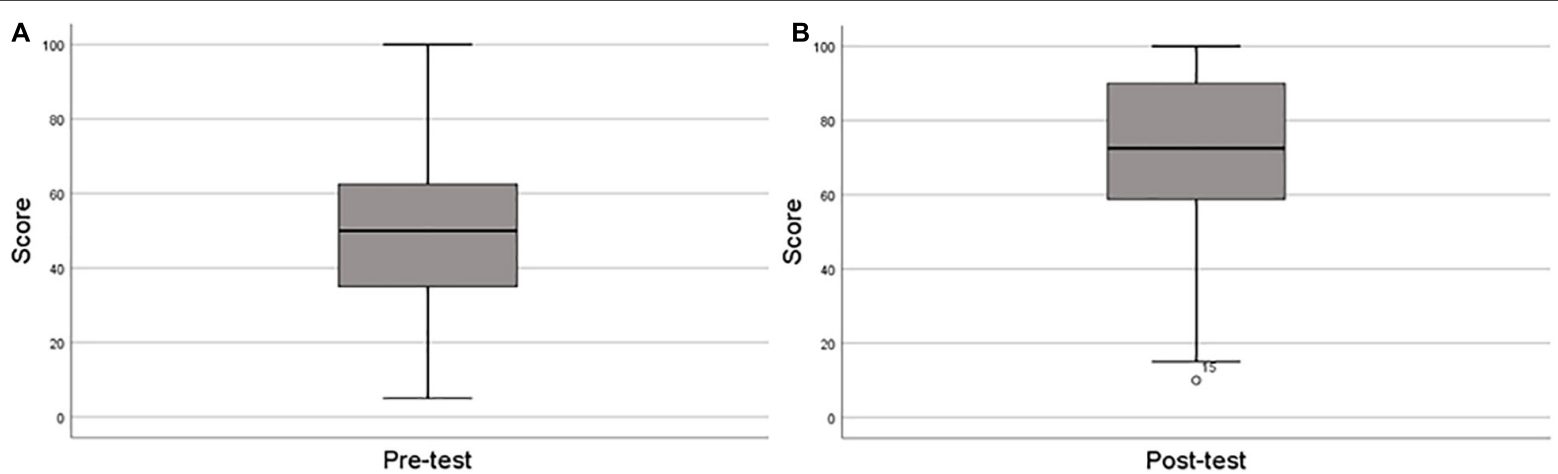

FIGURE 2 | Total scores for pre-test (A) and post-test (B). Middle line - median; box lower and upper limits - 1st and 3rd quantiles; points - outliers.

\section{RESULTS}

\section{Pre- and Post-test}

The analyses of the pre and post-tests applied to students $(n=292)$ revealed a statistically significant difference among the pre- and post-tests scores per student (Wilcoxon test, $p<0.001$ ), with a considerable higher score in the post-test (Figure 2).
The results of pre- and post-test relative frequency and percentage for each question answer (Table 2), showed an increase in students' knowledge related to: greenhouse effect (question 2), the effect of the rise of ocean water temperature on the species distribution (question 3) and the importance of monitoring the species distribution (question 4). In question 1 , the percentage of students that chose the correct answer 
TABLE 2 | Pre- and post-test relative frequency and percentage results for each question.

\begin{tabular}{|c|c|c|c|c|c|c|}
\hline \multirow[t]{2}{*}{ Question } & \multicolumn{2}{|l|}{ Answer } & \multicolumn{2}{|c|}{ Pre-test $(n=292)$} & \multicolumn{2}{|c|}{ Post-test $(n=292)$} \\
\hline & & & Frequency & Percentage & Frequency & Percentage \\
\hline \multirow[t]{5}{*}{$\begin{array}{l}\text { 1. What is climate } \\
\text { change? }\end{array}$} & \multicolumn{2}{|l|}{$\begin{array}{l}\text { Temperature and } \\
\text { precipitation changes in a } \\
\text { region over a long period of } \\
\text { time }\end{array}$} & 199 & 68 & 199 & 68 \\
\hline & \multicolumn{2}{|l|}{ Ocean plastics pollution } & 47 & 16 & 63 & 22 \\
\hline & \multicolumn{2}{|c|}{ The increase of animals and plants at the ocean } & 9 & 3 & 16 & 5 \\
\hline & \multicolumn{2}{|c|}{ Decrease of atmosphere temperature } & 23 & 8 & 12 & 4 \\
\hline & No answer & & 14 & 5 & 2 & 1 \\
\hline \multirow{10}{*}{$\begin{array}{l}\text { 2. Choose the correct } \\
\text { options to complete the } \\
\text { following image }\end{array}$} & \multirow[t]{2}{*}{ Answer for Sun } & Correct answer & 276 & 95 & 287 & 98 \\
\hline & & Incorrect answer & 15 & 5 & 7 & 2 \\
\hline & \multirow[t]{2}{*}{ Answer for Greenhouse effect } & Correct answer & 117 & 40 & 131 & 45 \\
\hline & & Incorrect answer & 175 & 60 & 161 & 55 \\
\hline & \multirow[t]{2}{*}{ Answer for Carbon Dioxide } & Correct answer & 100 & 34 & 121 & 41 \\
\hline & & Incorrect answer & 192 & 66 & 171 & 59 \\
\hline & \multirow[t]{2}{*}{ Answer for Earth } & Correct answer & 272 & 93 & 285 & 98 \\
\hline & & Incorrect answer & 200 & 7 & 7 & 2 \\
\hline & \multirow[t]{2}{*}{$\begin{array}{l}\text { Answer for greenhouse gas } \\
\text { emissions }\end{array}$} & Correct answer & 200 & 68 & 244 & 84 \\
\hline & & Incorrect answer & 92 & 32 & 48 & 16 \\
\hline \multirow{5}{*}{$\begin{array}{l}\text { 3. What can happen to } \\
\text { the species distribution } \\
\text { with the increase of } \\
\text { water temperature? }\end{array}$} & \multicolumn{2}{|l|}{ Complete answer } & 8 & 3 & 167 & 57 \\
\hline & \multicolumn{2}{|l|}{ Incomplete answer } & 127 & 43 & 72 & 25 \\
\hline & \multicolumn{2}{|l|}{ Wrong answer } & 133 & 46 & 45 & 15 \\
\hline & \multicolumn{2}{|l|}{ Imperceptible answer } & 8 & 3 & 3 & 1 \\
\hline & \multicolumn{2}{|l|}{ No answer } & 16 & 5 & 5 & 2 \\
\hline \multirow{5}{*}{$\begin{array}{l}\text { 4. How can we help the } \\
\text { scientists studying the } \\
\text { impact of climate } \\
\text { changes on species } \\
\text { distribution }\end{array}$} & \multicolumn{2}{|l|}{ Save water } & 106 & 36 & 52 & 18 \\
\hline & \multicolumn{2}{|l|}{ Recycling } & 44 & 15 & 13 & 4 \\
\hline & \multicolumn{2}{|c|}{ Monitoring the species distribution } & 111 & 38 & 210 & 72 \\
\hline & \multicolumn{2}{|l|}{ Using public transport } & 16 & 5 & 7 & 2 \\
\hline & \multicolumn{2}{|l|}{ No answer } & 16 & 5 & 10 & 3 \\
\hline
\end{tabular}

Correct answers are in bold.

remained the same (68\%), the percentage of students that chose the wrong option "decrease of atmosphere temperature" slightly diminished, and the percentage of answers "ocean plastics pollution" and "the increase of animals and plants at the ocean" increased comparing to pre-test results. In relation to question 2 , the percentage of students answering correctly increased in all items, specifically the answer for greenhouse gas emissions. For questions 3 and 4 , the results of the post-test revealed an increase of 54 and $34 \%$ of the number of students that gave a complete answer respectively (Table 2).

\section{Platform Observations}

The analysis of data from the online platform enabled assessment of the percentage of correct species identifications by students. It also enabled to assess what species were more frequently confused with others, such as prosobranch limpet species of the genus Patella or pulmonate limpets like Siphonaria pectinata.

Students developed ICT skills to record 407 observations, $41.8 \%$ of which were correctly identified. They were also able to observe 38 different taxa. Data from the different identified taxa showed that Patella depressa (116 observations), Siphonaria pectinata (28 observations) and Steromphala umbilicalis (26 observations) were the species more frequently observed (Table 3).

\section{Final Group Work - Exhibition}

The content analysis of the final group work, showed that all of them matched the theme of Ocean Literacy related to climate change and rocky shores. The works produced for the exhibition included posters $(n=16)$, flyers $(n=1)$ videos $(n=3)$, music $(n=1)$, oral presentations $(n=2)$, board games $(n=10)$ and scientific models $(n=3)$. The most relevant topics were the cause \& effect of the climate change on rocky shores, (52.8\%), the greenhouse effect concept $(30.6 \%)$ and the climate change concept (19.4\%).

Concerning content, $30.6 \%$ of the produced works were clear and objective showing fundamental factual knowlegde, $44.4 \%$ related and explained concepts and information correctly, and that $30.6 \%$ presented an extensive development of the theme, with the main idea supported with details (Table 4). 
TABLE 3 | Frequency of different taxa observed by students at Avencas Beach (Portugal).

\begin{tabular}{|c|c|c|}
\hline \multirow[t]{2}{*}{ Taxa } & \multicolumn{2}{|c|}{ Species' observation } \\
\hline & Frequency & Percentage \\
\hline Patella depressa & 116 & 28.5 \\
\hline Siphonaria pectinata & 28 & 6.9 \\
\hline Steromphala umbilicalis & 26 & 6.4 \\
\hline Corallina sp. & 18 & 4.4 \\
\hline Actinia equina & 17 & 4.2 \\
\hline Paracentrotus lividus & 16 & 3.9 \\
\hline Chthamalus sp., Phorcus sp. & 15 & 3.7 \\
\hline Anemonia viridis, Tritia reticulata & 13 & 3.2 \\
\hline Gastropoda, Ulva sp. & 11 & 2.7 \\
\hline Asparagopsis armata & 10 & 2.5 \\
\hline Lithophyllum incrustans, Mytillus sp., Patella sp. & 9 & 2.2 \\
\hline Actinia fragacea & 8 & 2.0 \\
\hline Marthasterias glacialis, Octopus vulgaris & 6 & 1.5 \\
\hline Chlorophyta, Patella ulyssiponensis, Sabellaria alveolata & 5 & 1.2 \\
\hline Brachyura, Carcinus maenas, Xanthidae & 3 & 0.7 \\
\hline Mesophyllum lichenoides, Paguroidea, Patella vulgata, Phorcus lineatus, Rodophyta & 2 & 0.5 \\
\hline Actinia sp., Anthozoa, Eulalia viridis, Fucacea, Lipophrys sp., Pachygrapsus marmoratus, Sphaerechinus granularis, Mimachlamys varia & 1 & 0.2 \\
\hline
\end{tabular}

Regarding general organization, $33.3 \%$ of the works were very well organized, with a good sequence and structured in themes, and $44.4 \%$ used an excellent vocabulary and included complex and meaningful words (Table 4). Finally, regarding creativity, $38.9 \%$ of the works were extremely creative in their content and the materials used (Table 4).

\section{DISCUSSION}

In the present study, climate change was used as an element for improving ocean literacy of elementary students. The impact of the activities on students' scientific content knowledge and skills, was assessed through a blended methodology. In general, we showed that the inquiry-based activity had a positive impact on their knowledge on cause \& effect of climate change and the importance of species distribution monitoring, as well as, on the development of marine species identification, and ICT skills due to participation in citizen science. Additionally, the final group work produced for the exhibitions also highlighted that the activities and being involved in citizen science action had a positive impact on the students collective development of skills, such as, decision making, collaborative work and communication. This reinforces the widely acknowledged idea that innovative and effective strategies for climate change education are needed (Gaudiano and Cartea, 2009), and can be successfully used to help enhance ocean literacy.

Pre and post-tests showed a significant difference between initial and final score, with the higher questionnaire score after the activities. So, as found in Boaventura et al. (2020) inquirybased activities about climate change had a positive impact on conceptual knowledge and in the development of investigation skills in students in this age range. A rather interesting finding was that in the first question the students seemed to share some difficulty to understand the definition of climate change. Most of the students seem to have misunderstood this concept, and chose the option related with ocean plastics pollution. This is possibly related to cultural misconceptions related to plastic pollution and low levels of correct information in the media (Gowda et al., 1997). Indeed, one of the challenges of climate change education is that the knowledge about climate change is highly affected by coverage in diverse media (Schreiner et al., 2005; Svihla and Linn, 2012). Some studies have shown that the ideas of students about climate change tended to be vague and general (Varma and Linn, 2012; Dawson, 2015) and that many hold misconceptions (Pruneau et al., 2001; Shepardson et al., 2009). The most common misconceptions are related with ozone depletion (Pruneau et al., 2001), and pollution in general (Koulaidis and Christidou, 1999). Nonetheless, all the work presented at the final exhibition were conceptually correct about climate change. This clearly demonstrated that the students had the opportunity to improve learning during the various activities and learn from each other by group work.

Learning about climate change in the context of the ocean also provided a set of opportunities for students to develop both their knowledge and several skills, especially investigation, problem solving and critical thinking (IAP, 2017; Burke et al., 2018; Tolppanen and Aksela, 2018). The analysis of final group work done by students showed that, at the end of the activities, they were able to incorporate all the learned scientific concepts and communicate their reflections to a wider audience in an objective, accurate and creative way. Trott and Weinberg (2020) suggested that climate change learning and action can support the engagement of children with science by emphasizing its real-world significance and by connecting learning with collaborative, community-based action. Through the group work, students had the opportunity to make collective decisions and communicate to the public, promoting also the two 


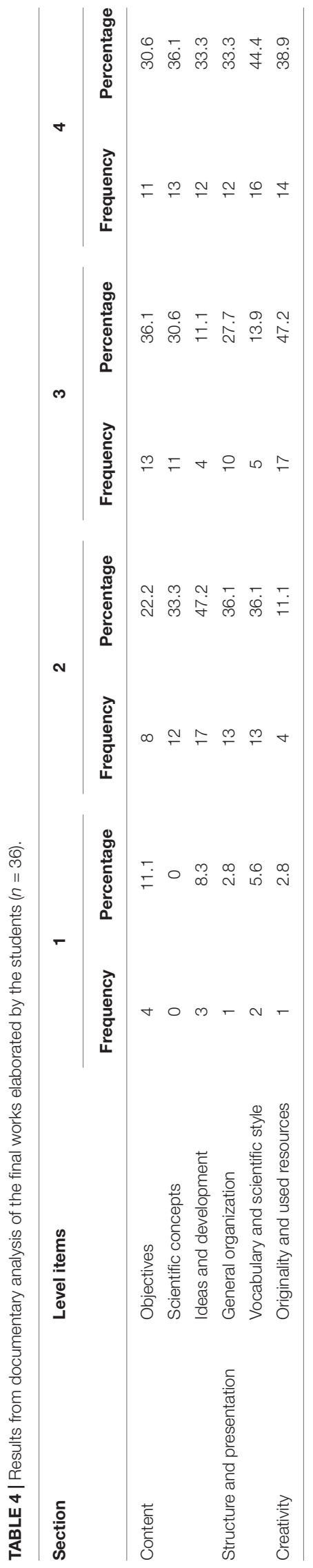

other recognized dimensions of Ocean Literacy - communication and decision-making (Fauville et al., 2018). Moreover, the citizen science activities contributed to develop marine species identification skills. Several studies have demonstrated that the participation in citizen science activities had a positive influence on species identification (Reis et al., 2013), along with important contribution to skills development, such as, observation, data collection, the use of scientific protocols, planning, critical thinking, problem solving, teamwork (Bonney et al., 2009; Hillar and Kitsantas, 2014; Queiruga and Saiz-Manzanares, 2018).

The combination of investigation activities with a citizen science activity had a positive result on knowledge and skills, promoting Ocean Literacy. The strategies implemented in our study allowed students to actively engage with the concepts, discuss their understanding and engage with relevant local examples of climate, such as, the cause \& effect of climate change on rocky shore ecosystems. Monroe et al. (2019) reinforced that good climate change education strategies should include field trips, data collection and community action projects. Also, our activities promoted the interaction with the scientists and, according with Hallar et al. (2011), the interaction with scientists who study climate change appear to motivate students learning.

Studies of this nature should assume particular importance in Portugal, as Ocean Literacy continues to be marginalized in formal curricular programs (Fauville et al., 2012). According to OECD (2018) the principal obstacles to the inclusion of Ocean Literacy in Portuguese curricula are the excessive fragmentation of curricula into many disciplines, the size of the current programs and the reduced practice of interdisciplinary projects and problem-based learning. However, the recent legislation (no. 55/2018) allowed schools to integrate innovative methodologies and practices representing an opportunity to explore the Ocean Literacy in Portuguese schools. Ultimately, "ocean-literate individuals take action, and through active participation in OL experiences, attach emotion and values to the ocean and its resources" (Barracosa et al., 2019).

Our study reinforces the importance of addressing Ocean Literacy using climate change through formal and non-formal educational activities with an investigative nature. In the future, it will be important to tackle other ocean literacy principles and to promote initiatives including climate change mitigation and adaptation. As for the citizen science action successfully trialed here with elementary school children, it is essential to keep on with such monitoring activities to promote long-term data series (with suitable quality control) and to develop of cocreated approaches, between researchers and scholar community, to deepen students and teachers' participation.

\section{DATA AVAILABILITY STATEMENT}

The datasets presented in this study can be found in online repositories. The names of the repository/repositories and accession number(s) can be found below: https://www. biodiversity4all.org/projects/edumar, Biodiversity4All. 


\section{ETHICS STATEMENT}

The studies involving human participants were reviewed and approved by Comissão de Ética para a Investigação em Educação, Escola Superior de Educação João de Deus. Written informed consent to participate in this study was provided by the participants' legal guardian/next of kin. Written informed consent was obtained from the individual(s), and minor(s)' legal guardian/next of kin, for the publication of any potentially identifiable images or data included in this article.

\section{AUTHOR CONTRIBUTIONS}

All authors listed have made a substantial, direct and intellectual contribution to the work, and approved it for publication.

\section{FUNDING}

This publication was financed by Portuguese national funds through FCT - Fundação IP under project reference

\section{REFERENCES}

ALLEA (2020). A Snapshot of Climate Change Education Initiatives in Europe: Some initial findings and implications for future Climate Change Education research. Lead authors: Cliona Murphy, Gabriela Martinez Sainz, Maija Aksela, Gerd Bergman, Michael Jones, Pierre Léna, David Wilgenbus. Berlin: ALLEA, doi: $10.26356 /$ climateeducation

Anderson, A. (2012). Climate change education for mitigation and adaptation. J. Educ. Sustain. Dev. 6, 191-206. doi: 10.1177/0973408212475199

Barracosa, H., de los Santos, C. B., Martins, M., Freitas, C., and Santos, R. (2019). Ocean literacy to mainstream ecosystem services concept in formal and informal education: the example of coastal ecosystems of southern Portugal. Front. Mar. Sci. 6:626. doi: 10.3389/fmars.2019.00626

Bates, A. J., Fraser, P. L., Robinson, L., Tweddle, J. C., Sadler, J. P., West, S. E., et al. (2015). The OPAL bugs count survey: exploring the effects of urbanisation and habitat characteristics using citizen science. Urb. Escosyst. 18, 1477-1497. doi: 10.1007/s11252-015-0470-8

Berchez, F. A., Ghilardi-Lopes, N. P., Correia, M. D., Sovierzoski, H. H., Pedrini, A. G., Ursi, S., et al. (2016). Marine and coastal environmental education in the context of global climate changes-synthesis and subsidies for ReBentos (Coastal Benthic Habitats Monitoring Network). Braz. J. Ocean. 64, 137-156. doi: 10.1590/S1679-875920160932064sp2

Boaventura, D., Faria, C., and Guilherme, E. (2020). Impact of and inquiry-based science activity about climate change on development of primary students' investigation skills and conceptual knowledge. Int. J. Environ. Sci. Educ. 16:e2225. doi: 10.29333/ijese/8554

Bonney, R., Ballard, H., Jordan, R., McCallie, E., Phillips, T., Shirk, J., et al. (2009). Public Participation in Scientific Research: Defining the Field and Assessing Its Potential for Informal Science Education. A CAISE Inquiry Group Report. Washington, D.C: Center for Advancement of Informal Science Education (CAISE).

Borja, A., Santoro, F., Scowcroft, G., Fletcher, S., and Strosser, P. (2020). Editorial: connecting people to their oceans: issues and options for effective ocean literacy. Front.Mar.Sci. 6:837. doi: 10.3389/fmars.2019.00837

Burke, S. E. L., Sanson, A. V., and Van Hoorn, J. (2018). The psychological effects of climate change on children. Curr. Psychiatry Rep. 20:35. doi: 10.1007/s11920018-0896-9

Cava, F., Schoedinger, S., Strang, C., and Tuddenham, P. (2005). Science Content and Standards for Ocean Literacy. Available online at: https://www.
UIDB/04292/2020 and by the European Union's Horizon 2020 Research and Innovation Programme under grant agreement N810139: Project Portugal Twinning for Innovation and Excellence in Marine Science and Earth Observation PORTWIMS. This research was done under the project "EDUcar para o MAR" - EDUMAR (SAICT-POL/23480/2016), financially supported by Portugal 2020, Foundation for Science and Technology - FCT (PIDDAC) and by the European Union, through the European Regional Development Fund (LISBOA-01-0145-FEDER-023480/CENTRO-01-0145-FEDER023480). Researcher fellowships were granted by FCT to AN (BIM/ESEJD/23480/2017), to CL (SFRH/BPD/100511/2014), and to AM (SFRH/BGCT/106026/2015).

\section{ACKNOWLEDGMENTS}

We thank the schools involved in the project: Jardins-Escolas João de Deus da Estrela, Alvalade, Olivais and Odivelas, and Agrupamento Padre Bartolomeu de Gusmão, including the students and teachers who participated, and the students of Escola Superior de Educação João de Deus.

coexploration.org/oceanliteracy/documents/OLit2004-05_Final_Report.pdf (Accessed December 22, 2020)

Cummins, S., and Snively, G. (2000). The effect of instruction on children's knowledge of marine ecology, attitudes toward the ocean, and stances toward marine resource issues. Can. J. Environ. Educ. 5, 305-324.

Dawson, V. (2015). Western Australian high school students' understandings about the socioscientific issue of climate change. Int. J. Sci. Educ. 37, 1024-1043. doi: 10.1080/09500693.2015.1015181

Doney, S. C., Ruckelshaus, M., Emmet Duffy, J., Barry, J. P., Chan, F., Chad, A. E., et al. (2011). Climate change impacts on marine ecosystems. Annu. Rev. Mar. Sci. 4, 11-37. doi: 10.1146/annurev-marine-041911-111611

Fauville, G., Säljö, R., and Dupont, S. (2012). Impact of ocean acidification on marine ecosystems: educational challenges and innovations. Mar. Biol. 160, 1863-1874. doi: 10.1007/s00227-012-1943-4

Fauville, G., Strang, C., Cannady, M. A., and Chen, Y.-F. (2018). Development of the international ocean literacy survey: measuring knowledge across the world. Environ. Educ. Res. 25, 238-263. doi: 10.1080/13504622.2018.1440381

Firth, L. B., and Hawkins, S. J. (2011). Introductory comments-global change in marine ecosystems: patterns, processes and interactions with regional and local scale impacts. J. Exp. Mar. Bio. Eco. 400, 1-6. doi: 10.1016/j.jembe.2011.02.001)

Gaudiano, E. G., and Cartea, P. M. (2009). "Climate change education and communication: a critical perspective on obstacles and resistances," in Education and Climate Change: Living and Learning in Interesting Times, eds F. Kagawa and D. Selby (New York, NY: Routledge), 13-31.

Gowda, M. V. R., Fox, J. C., and Magelky, R. D. (1997). Students' understanding of climate change: insights for scientists and educators. Bull. Am. Meterol. Soc. 78, 2232-2234.

Hallar, A. G., McCubbin, I. B., and Wright, J. M. (2011). Change: a placebased curriculum for understanding climate change at storm peak laboratory, Colorado. Bull. Am. Meteorol. Soc. 92, 909-918. doi: 10.1175/2011BAMS3026.1

Hawkins, S. J., Pack, K. E., Firth, L. B., Mieszkowska, N., Evans, A. J., Martins, G. M., et al. (2019). "The intertidal zone of the Northeast Atlantic region: patterns and processes," in Interactions in the Marine Benthos. Global Patterns and Processes. The Systematics Association, eds S. J. Hawkins, B. Katrin, L. Firth, and G. A. Williams (Cambridge: Cambridge University Press), 7-46.

Hawkins, S. J., Sugden, H. E., Mieszkowska, N., Moore, P. J., Poloczanska, E., Leaper, R., et al. (2009). Consequences of climate-driven biodiversity changes for ecosystem functioning of North European rocky shores. Mar. Ecol. Prog. Ser. 396, 245-259. doi: 10.3354/meps08378 
Helmuth, B., Mieszhowska, N., Moore, P., and Hawkins, S. J. (2006). Living on the edge of two changing worlds: forecasting the responses of rocky intertidal ecosystems to climate change. Annu. Rev. Ecol. Evol. Syst. 37, 373-404. doi: 10.1146/annurev.ecolsys.37.091305.110149

Hillar, S. E., and Kitsantas, A. (2014). The effect of a horseshoe crab citizen science program on middle school student science performance and STEM career motivation. Sch. Sci. Math. 114, 302-311. doi: 10.1111/ssm.12081

IAP (2017). Inter Academy Partnership Statement on Climate Change Education. Available online at: https://www.interacademies.org/statement/statementclimate-change-and-education (Accessed December 10, 2020)

IPCC (2017). Climate Change 2017: Synthesis Report. Contribution of Working Groups I, II and III to the Fifth Assessment. Geneva: IPCC.

Jordan, R. C., Gray, S. A., Howe, D. V., Brooks, W. R., and Ehrenfeld, J. G. (2011). Knowledge gain and behavioral change in citizen-science programs. Conserv. Bio. 25, 1148-1154. doi: 10.1111/j.1523-1739.2011.01745.x

Kordas, R. L., Harley, C. D. G., and O'Connor, M. I. (2011). Community ecology in a warming world: the influence of temperature on interspecific interactions in marine systems. J. Exp. Mar. Biol. Ecol. 400, 218-226. doi: 10.1016/j.jembe. 2011.02.029

Körfgen, A., Keller, L., Kuthe, A., Oberrauch, A., and Stötter, J. (2017). Climate Change in young people's minds-From categories towards interconnections between the anthroposphere and natural sphere. Sci. Total Environ. 580, 178187. doi: 10.1016/j.scitotenv.2016.11.127

Koulaidis, V., and Christidou, V. (1999). Models of students' thinking concerning the greenhouse effect and teaching implications. Sci. Educ. 83, 559-576.

Lima, F. P., Ribeiro, P. A., Queiroz, N., Hawkins, S. J., and Santos, A. M. (2007). Do distributional shifts of northern and southern species of algae match the warming pattern? Glob. Change Biol. 13, 2592-2604. doi: 10.1111/j.1365-2486. 2007.01451x

McCright, A. M., O'Shea, B. W., Sweeder, R. D., Urquhart, G. R., and Zekele, A. (2013). Promoting interdisciplinary through climate change education. Nat. Clim. Change 3, 713-716. doi: 10.1038/NCLIMATE 1844

Miller-Rushing, A., Primack, R., and Bonney, R. (2012). The history of public participation in ecological research. Front. Ecol. Environ. 10:285-290. doi: 10. $1890 / 110278$

Mogias, A., Boubonari, T., Realdon, G., Previati, M., Mokos, M., Koulouri, P., et al. (2019). Evaluationg ocean literacy of elementary school students: preliminary results of a cross-cultural study in the mediterranean region. Front. Mar. Sci. 6:396. doi: 10.3389/fmars.2019.00396

Monroe, C. M., Plate, R. R., Oxarart, A., Bowers, A., and Willandia, A. C. (2019). Identifying effective climate change education strategies: a systematic review of the research. Environ. Educ. Res. 25, 791-812. doi: 10.1080/13504622.2017. 1360842

National Oceanic and Atmospheric Administration (2013). Ocean Literacy: the Essential Principles and Fundamental Concepts of Ocean Sciences for Learners of All Ages Version 2. College Park, MD: National Oceanic and Atmospheric Administration,

OECD (2018). Curriculum Flexibility and Autonomy in Portugal-an OECD Review. Available online at: https://www.oecd.org/education/2030/ Curriculum-Flexibility-and-Autonomy-in-Portugal-an-OECD-Review.pdf. (Accessed February 17, 2021)

Oversby, J. (2015). Teachers' learning about climate change education. Proc. Soc. Behav. Sci. 167, 23-27.

Perkins, K. M., Munguia, N., Moure-Eraso, R., Delakowitz, B., Giannetti, B. F., Liu, G., et al. (2018). International perspectives on the pedagogy of climate change. J. Clean. Prod. 200, 1043-1052. doi: 10.1016/j.jclepro.2018.0 7.296

Pruneau, D., Moncton, U., Liboiron, L., and Vrain, E. (2001). People's idea about climate change: a source of inspiration for the creation of educational programs. Can. J. Environ. Educ. 6, 58-76.

Queiruga, M., and Saiz-Manzanares, M. (2018). “Citizen science in school," in Hands-on Science. Advancing Science. Improving Education, eds M. Costa, J. Dorrío, and J. Novell (Braga: Copissaurio Repro - Centro Imp.), 194-198.

Ratinen, I., Viiri, J., and Lehesvuori, S. (2013). Primary school student teachers' understanding of climate change: comparing the results given by concept maps and communication analysis. Res. Sci. Educ. 43, 1801-1823. doi: 10.1007/ s11165-012-9329-7

Reis, C. S., Marchante, H., Freitas, H., and Marchante, E. (2013). Public perception of invasive plant species: assessing the impact of workshop activities to promote young students' awareness. Int. J. Sci. Educ. 35, 690-712. doi: 10.1080/09500693. 2011.610379

Santoro, F., Santi, S., Scowcrof, G., Fauville, G., and Tuddenham, P. (2017). Ocean Literacy for All - a Toolkit. Paris: UNESCO Venice Office,

Saunders, M. E., Roger, E., Geary, W. L., Meredith, F., Welbourne, D. J., Bako, A., et al. (2018). Citizen science in schools: engaging students in research on urban habitat for pollinators. Aust. Ecol. 43, 635-642. doi: 10.1111/aec.1 2608

Schreiner, C., Henriksen, E., Kirkeby, H., and Pal, J. (2005). Climate education: empowering today's youth to meet tomorrow's challenges. Stud. Sci. Educ. 41, 3-49. doi: 10.1080/03057260508560213

Shepardson, D. P., Niyogi, D., Choi, S., and Charusombat, U. (2009). Seventh grade students" conceptions of global warming and climate change. Environ. Educ. Res. 15, 549-570. doi: 10.1080/13504620903114592

Southward, A. (1980). The Western English Channel-an inconstant ecosystem? Nature 285, 361-366. doi: 10.1038/285361a0

Stefanelli-Silva, G., Pardo, J. C. F., Paixão, P., and Costa, T. M. (2019). University extension and informal education: useful tools for bottom-up Ocean and coastal literacy of primary school children in Brazil. Front. Mar. Sci. 6:389. doi: 10.3389/ fmars.2019.00389

Svihla, V., and Linn, M. C. (2012). A design-based approach to fostering understanding of global climate change. Int. J. Sci. Educ. 3, 651-676. doi: 10. 1080/09500693.2011.597453

Tolppanen, S., and Aksela, M. (2018). Identifying and addressing students' questions on climate change. J. Sci. Educ. 49, 375-389. doi: 10.1080/00958964. 2017.1417816

Trott, C. D., and Weinberg, A. E. (2020). Science education for sustainability: strengthening children's science engagement through climate change learning and action. Sustainability 12:6400. doi: 10.3390/su12166400

UNESCO (1975). The International Workshop on Environmental Education Final Report. Belgrade: UNESCO/UNEP,

UNESCO (2017). Education for Sustainable Development Goals. Learning Objectives. Paris: United Nations Educational and Cultural Organization,

Uyarra, M. C., and Borja, A. (2016). Ocean literacy: a 'new' socio-ecological concept for a sustainable use of the seas. Mar. Pollut. Bull. 104, 1-2. doi: 10.1016/j. marpolbul.2016.02.060

Varma, K., and Linn, M. C. (2012). Using interactive technology to support students' understanding of the greenhouse effect and global warming. J. Sci. Educ. Tech. 21, 453-464. doi: 10.1007/s10956-011-9337-9

Vye, S. R., Dickens, S., Adams, L., Bohn, K., Chenery, J., Dobson, N., et al. (2020). Patterns of abundance across geographical ranges as a predictor for responses to climate change: evidence from UK rocky shores. Divers. Distrib. 26, 1357-1365. doi: 10.1111/ddi.1 3118

Conflict of Interest: The authors declare that the research was conducted in the absence of any commercial or financial relationships that could be construed as a potential conflict of interest.

Publisher's Note: All claims expressed in this article are solely those of the authors and do not necessarily represent those of their affiliated organizations, or those of the publisher, the editors and the reviewers. Any product that may be evaluated in this article, or claim that may be made by its manufacturer, is not guaranteed or endorsed by the publisher.

Copyright (c) 2021 Boaventura, Neves, Santos, Pereira, Luís, Monteiro, Cartaxana, Hawkins, Caldeira and Ponces de Carvalho. This is an open-access article distributed under the terms of the Creative Commons Attribution License (CC BY). The use, distribution or reproduction in other forums is permitted, provided the original author(s) and the copyright owner(s) are credited and that the original publication in this journal is cited, in accordance with accepted academic practice. No use, distribution or reproduction is permitted which does not comply with these terms. 